\title{
We Can Teach Art, but Can Art Teaches Us? John Dewey on the Significance of Art
}

\section{Rio Adiwijaya}

New Media Program, Visual Communication Design Department, School of Design, Bina Nusantara University, Jakarta, Indonesia 11480, PhD Student of STF Driyarkara, Jakarta, Indonesia, 10520.

E-mail: dadiwijaya@binus.edu |rioadi@gmail.com

\begin{abstract}
Those who pursue a teaching career in art and design are most likely aware of one of its pressing dilemmas. On the one hand, as a subject situated in the postindustrial higher education setting where the progressive accumulation of knowledge - mostly in propositional form and explaining how things work in physical or social reality - constitutes its main purpose, art are unavoidably driven to adopt the same objective. On the other hand, most artistic activities are not aimed to produce and derived from replicable research propositions but conducted to generate novel artifacts, performances, narratives or experiences in order to enhance artistic universe. Regarding their being as artifactual, non-propositional and idiosyncratic, artworks are unfortunately regarded as mere products of subjective emotions, where it's appropriate roles are nothing more than spectacles, entertainments or ornaments, which at the same time testify its marginal relationship with knowledge. However, this predicament is not as self-evident as it looks since it is in fact resulted from a particular philosophical outlook, namely, an outlook that bifurcates mind and body, rational and emotional, subject and object, and so forth that comes down to us from the Platonic and Cartesian tradition. It is precisely the thought of John Dewey that profitably conceives art prior to Platonic/Cartesian bifurcation which will be discussed in this paper. Art, for Dewey, is not a product of a mere subjectivity, but instead emerges from "experience," understood as primary, pre-linguistic (hence pre-dualism) and embodied human-environment "transactions." Located in such a primary domain, art regains its utmost significance.
\end{abstract}

Keywords: art, knowledge, bifurcations of thought, John Dewey, experience

\begin{abstract}
Abstrak
Mereka yang mengejar karir dosen di bidang seni dan desain kemungkinan besar menyadari salah satu dilemanya yang mendesak. Di satu sisi, sebagai bidang yang berada dalam lingkungan pendidikan tinggi pasca-industri di mana akumulasi pengetahuan progresif - kebanyakan dalam bentuk proposisional dan menjelaskan bagaimana hal-hal bekerja dalam realitas fisik ataupun sosial - merupakan tujuan utamanya, seni secara tidak terhindarkan didorong untuk mengadopsi tujuan yang sama. Di sisi lain, sebagian besar kegiatan artistik tidak bertujuan untuk menghasilkan, dan berasal dari proposisi penelitian yang dapat direplikasi namun dilakukan untuk menghasilkan artefak, performa, narasi atau pengalaman baru dalam rangka mengembangkan semesta artistik. Melihat keberadaan seni yang serba artifaktual, non-proposisional dan unik, karya seni dianggap sebagai
\end{abstract}


semata-mata produk dari emosi subjektif, di mana perannya dianggap tidak lebih dari tontonan, hiburan atau ornamen, yang pada saat yang sama menyiratkan hubungannya yang marginal dengan pengetahuan. Namun, dilema ini bukan sesuatu yang sudah jelas dengan sendirinya, karena nyatanya dihasilkan dari pandangan filosofis tertentu, yaitu, pandangan yang membelah tajam antara pikiran dan tubuh, rasional dan emosional, subjek dan objek, dan sebagainya yang diturunkan pada kita dari tradisi Platonis dan Cartesian. Adalah pemikiran proseni dari John Dewey yang bergerak sebelum bifurkasi Platonis/Cartesian yang akan dibahas dalam makalah ini. Seni, bagi Dewey, bukan produk dari subjektivitas belaka, melainkan muncul dari "pengalaman," dipahami sebagai "transaksi" manusia-lingkungan yang bersifat primer, pra-linguistik (oleh karena itu pra-dualisme) dan menubuh (artifaktual). Diletakkan di ranah semendasar ini, seni mendapatkan kembali signifikansi terpentingnya.

Kata Kunci: seni, pengetahuan, bifurkasi pemikiran, John Dewey, pengalaman

\section{INTRODUCTION}

In many world societies that are increasingly tied to the global network of information economy, there is nothing more precious to cultivate than knowledge. Accordingly, policy conceptualizations within the global economy tend to prioritize programs and fundings for knowledge areas having the highest possible economical impact, namely, techno-scientific research (Duby \& Barker, 2017:1). This kind of policy has challenged the future of faculties such as traditional humanities and creative arts, for their alleged speculative and aesthetic traits are regarded as insignificant in techno-economical terms. The emergence of the exciting yet polemical notion of creative arts as research is in part driven by this kind of policy conceptualization (Cazeaux, 2017: 1-4). But can art truly become research in a traditional sense? How could we comprehend the idea of creative arts as research or as 'knowledge production' while its outcomes are still primarily artworks and/or performances rather than verbal propositions that systematically explain, predict or describe how things work in our natural and cultural world? Where can we find art's truth value? Are they implied in the written concepts? However, no matter how invaluable verbal concepts are, they do not isomorphically translate into, and from artworks and/or performances. For how can we premeditate and/or 'paraphrase' isomorphically in verbal terms, let us say, a picture or a musical piece?

Immediately sensed aesthetic dimensions is stubbornly present in all art creations and receptions. And unlike scientific or social research which attempt to 'represent the actual' through explanatory and descriptive verbal propositions, art foremostly 'present the possible' through direct presence or performativity of sensory works. So, in what way that we can comprehend art's significance as research driven knowledge? If we insist that artistic research and its knowledge are necessarily embodied in the artifacts and performances, there are many fundamental 
questions concerning embodied knowledge itself that should be answered, e.g., what kind of knowledge it in fact, is? How can sensory works and/or performances embodying 'imaginative' content be regarded as equal to 'factuality' of scientific propositions resulting from rigorous research? (Pakes, 2004: 1). Does embodied knowledge in art have equal explanatory / predictive / descriptive roles as explicit propositional knowledge? If it does not, then art is still ensnared in the domain of 'aesthetics.' The question is then, how can we make sense of art and aesthetic experiences in a more significant way than deeming it to be a merely subjective affair (Johnson, 2018: 1-3, Shusterman, 1997: 29 and, 2012: 107).

Fortunately, difficulties we face in finding significant meaning of art and aesthetic experience are not results of some self-evident facts (i.e. that art is selfevidently a mere subjectivistic affair) since the allegedly self-evident fact itself is already a logical consequence of a particular philosophical (i.e., metaphysical and epistemological) view. Following John Dewey's philosophical hint, our tendency to make sense of art and aesthetic experiences as a merely subjective phenomenon is precisely follows from an unrealized philosophical view that bifurcates the mind and the body, rational and emotional, subject and object, and so forth in the first place, a view which actually comes down to us from the Platonic and the Cartesian tradition (Johnson, 2018: 73-74, and, 2011: 143, Gamo, 2011: 85-87). As Dewey (1859-1952) has argued at length, subject and object are not self-evident 'facts' but instead a product of history of philosophy. It follows that far from being an absolute, this conception can be deconstructed, allowing us at the same time to make sense of art and aesthetic experience in a more constructive or positive way. Accordingly, this study has two aims. Firstly, is to deconstruct the dualistic metaphysics, and secondly, to construct a more significant understanding of art in accordance to Dewey's understanding of experience.

In appropriating Dewey's complex yet rich understanding of aesthetic experience as primary modes of human existence which is always in contact with reality, this study employs literary research of selected primary and secondary texts. But firstly Dewey's basic philosophical position should be introduced here. John Dewey is the key proponent of American Pragmatism, a school of thought that rejects dualistic metaphysics and epistemology of modern philosophy (Malachowski, 2013: 81-82, 128, 346), and alternatively advocates a strong naturalistic view of knowledge as arising from active and continuous processes of adaptation of human organisms to their lived environment (ibid., 2013: 64, 134). The primary starting point of Dewey's pragmatic naturalism is to approach the world as we experience it in a direct, immediate and pre-reflective way prior to conceptual split between the mind and the body or subject and object (Muhit, 2013: 13-16). In this manner, Dewey pursues a holistic ontology of events (Macey, 1994: 165 ) in which the world and ourselves are no longer understood as two separate 
substances, but rather as co-emergent happenings which admit both of its episodic uniqueness (Deweyan locus for art) as well as its general regularities (Deweyan locus for science) (Johnson, 2011: 149-150). However, this very brief study is only sufficed to highlight some of Dewey's key notions regarding experience, which in consecutive order are: the 'stretched' or spatial character of experience, the temporal character of aesthetic experience, and how can art becomes significant on the ground of Dewey's broad understanding of experience.

\section{DEWEY AGAINST INTELLECTUALISTIC DUALISM}

Difficulties we encounter in recognizing art's sensory presence or performativity as embodying significant understanding, albeit non-verbal, according to Deweyan view are due to the old yet prevailing philosophical notion that bifurcates mind from body, intelligible from sensible, thought from feeling, facts from values, spiritual from material, thinking from doing/making, et cetera, and places the former half of each binary pair as more primary, essential in human beings and superior than the latter. Mind or reason, for example, is commonly taken to be superior faculties compared to bodily senses. From this 'intellectualistic dualism' rooted in Platonic philosophy, knowledge is seen as an abstract thing or a fixed body of propositions representing the true Forms or real essence of things, attainable only through human intellect insofar it is 'purified' from any sensory or emotional biases. Accordingly, art as an epitome of the sensory definitely appears as having no significant relation to true knowledge.

Modern philosophy since Descartes has brought deeper complications by inducing more segregation into Platonic dualism, namely, the sharp division between subject and object, inner and outer, self and world. Thanks to Cartesianism, there are now familiar divisions between what is considered to be merely subjective or occurring inside the mind, and truly objective or taking place in the outside world (Muhit, 2013:10; Gamo, 2011: 85-86). The impact of this Cartesian dualism to art is more devastating. For being a result of our own creative act, art appears to be a mere sensory externalization of our own subjective fantasy or feeling, and in turn, it causes in its viewers merely subjective emotional responses rather than rationally objective understanding of the world. Conversely, it is science that is granted a status as a genuine form of knowledge, for its allegedly passive, detached and purely cognitive way of inquiry is regarded to have resulted propositional body of claims that objectively represent the external world. Insofar we still hold on to this old metaphysical dualism or the "folk theory of disembodied mind' (Johnson, 2018: 3-4) which prioritize the mind over the body, any attempt to give art a significant status as embodying true knowledge seems to end in vain. 
The question is, then, how can we make sense of ourselves, the world, and the arts beyond the 'perimeters' of the all too familiar Platonic/Cartesian binary? Following Dewey, one of the critical ways is to see that bifurcated oppositional pairs such as mind versus body, cognitive versus aesthetic, subject versus object, inner versus outer, et cetera, are not actual constitutions of the real but instead results of philosophical conceptualization. However, Dewey is not against conceptualizations per se for he himself is a philosopher whose job is making conceptual distinctions. One thing we should carefully avoid is to fall into "fallacy of hypostatization," which is defined by Dewey as "conversion of eventual functions into antecedent existence" (Dewey, 1981: 34). When we reify some static quasi-entities out of the temporal flow of concrete life that precedes any philosophical conceptualization, hypostatization fallacy occurs (Fesmire, 2015: 8586). In other words, we commit the fallacy when we treat abstract concepts as selfsufficient entities and forgetting their origin as results of analysis (as in the case of Cartesian res cogitans or mind, which is conceived by Descartes to be a real 'mental thing' which truly exists independently from the body or material thing).

To avoid such fallacy which contributes to fatal conceptual segregation and compartmentalization of life, Dewey himself prefers the term 'body-minds' (Cochran, 2010:126) to "capture the intimate and intricate interaction of the corporeal, interpersonal, and cultural dimensions of our selfhood. Body and mind are not separate realities, but rather aspects or dimensions of a process of organismenvironment interaction, in which organism and environment are interrelated, interdependent, and interdefined" (Johnson, 2018:14). Indeed, Dewey did not merely play around with neologisms but wholeheartedly anchoring his philosophy in Experience and Nature and Art as Experience in the temporal continuum of life context prior to mind-body, subject-object, or self-world split.

\section{LIFE AS SPATIALLY STRETCHED EXPERIENCE}

If one begins from hypostatized mind-body or subject-object split, the only logical way to bridge the allegedly 'natural' gap between the split is through the mediation of explicit propositional knowledge (since we assume that we are solely thinking subjects). In an almost comparable fashion to phenomenology, Dewey radicalized version of naturalism emphasizes the primacy of his version of Lebenswelt, the lived-world prior to our conceptual separation between ourselves and the world (Fesmire, 2011:112, Malachowski, 2013:7), hence we and the world are not yet separated mind and world, or subject and object. In this raw, unmediated and prereflective mode of existence, we and the world, according to Dewey, are both parts of continually developing flow of organism-environment transactions. We live and become who we are only in and through series of embodied interactions with multivarious facets of our physical and socio-cultural environment. In this pre- 
theoretical yet primary mode of existence, our interactions are directly experienced rather than mediated by mental concepts. Since it signifies our unmediated interactions, experience for Dewey is neither a psychological event that occurs inside the mind nor merely felt occurrence of physical stimulus.

"Experience is of as well as in nature. It is not experience which is experienced, but nature-stones, plants, animals, diseases, health, temperature, electricity, and so on. Things interacting in certain ways are experience; they are what is experienced. Linked in certain other ways with another natural object - the human organism-they are how things are experienced as well. Experience thus reaches down into nature; it has depth. It also has breadth and to an indefinitely elastic extent. It stretches." (Dewey, 1981: 12-13)

In other words, life itself primarily occurs as a field of experience that encompasses both organism and environment, rather than constituted by the presence of atomistic subjects standing over against the world of objects through mediation of explicit cognizance. Indeed, this is Dewey's basic philosophical stance in overcoming intellectualistic dualism.

However, how can people orient their life without being mediated or informed by some instances of explicit knowledge? Dewey's answer is primarily through directly felt pervasive quality of experience itself. Mark Johnson has an excellent illustration:

"We dwell in a world of qualities... the fresh, earthy scent of a cool breeze coming in through the window on a spring morning, the sounds of children playing, the honking of horns in congested traffic accompanied by the smell of exhaust and the feeling of cars and trucks pressing in around us, and the refreshing shock of the cold mountain lake after a strenuous sweaty hike. We act to realize some qualities and avoid others... all of which are experienced qualitatively without any need for reflective thought." (Johnson, 2018:247)

Our interactions in/with the world are indeed meaningful even without explicit language, as when we silently exchange gestures with others in daily interactions, or effortlessly enjoy our drive around town without having to think consciously about car mechanism and maps. This is not to say that symbolic language has no role in enriching our possibilities for meaningful interactions. Instead, Dewey's point is that linguistic meaning is parasitic on embodied qualitative meaning, and not the other way around. The problem is, intellectualistic dualism has deemed the qualitative aspect of experience as merely residing 'inside' the human 'mind.' In other words, quality is deemed to be merely 'subjective.' However, since subject-object and inside-outside split themselves are results of hypostatization, putting quality in the subject's mind and quantity in the objective world is even more untenable! For Dewey, immediately felt pervasive qualities belong to the world as well as to the 
humans. It is neither subjective nor objective but encompasses both, insofar as both the experiencer and the experienced interact.

As can be expected, this qualitatively meaningful field of embodied experience is precisely the Deweyan philosophical context for making sense of creative arts in a very significant way. However, there is still more to say about experience since it is precisely Dewey's most central concept and considered to be more primary than knowledge. Furthermore, whenever we are immersing in qualitatively meaningful experience, for Dewey, we are dwelling in its most primary mode (Ruoppa, 2019:69; McClelland, 2005: 47-48). Conversely, our conscious, conceptually mediated, and detached encounter with the world constitutes secondary mode of experience. Overall flow of one's life experience hence consists of switching back and forth between its primary and secondary mode, whereas the latter always comes from and feeds back to the former in terms of achieving its fuller or more consummatory phase. These cycles of feedback loops eventually make possible one's life experience as a whole to be continuously developing (Fesmire, 2015:71; 192), transforming a person's state from less experienced to become more cultivated.

Recognizing this difference between primary and secondary experience is also crucial in understanding Dewey's differentiation between art and science (Ruoppa, 2019:62). Art, due to its sensory or embodied character, mostly operates in primary mode of experience by enacting directly sensed qualitative meanings and values via artworks. In contrast to art, science with its abstract-conceptualizing character that seeks generalizations operates mostly in secondary mode of experience (Johnson, 2011:147.) However, since secondary experience always emerges from, and feeds back into the primary one, science in the Deweyan sense can also be said to be art, albeit involving its own qualities, i.e., its norms and ideals (Johnson, 2011: 149-150.). However, since secondary or detached experience always emerges from, and feeds back to the primary and immediate one, science in the Deweyan sense can also be said to be a kind of art, albeit involving its own qualities, i.e., its own norms and ideals. And lastly, since the whole life itself for Dewey is a temporal flow of experience taken at large (i.e., human cultural history), art and science's most profound role is continuously improving how the world is qualitatively experienced by ourselves. In other words, science is not a set of fact-stating propositions and art is not a set of artifacts that express irrational subjectivities, but rather, they are two different kind of experience-improving human affairs whose basic existence is marked by ongoing socio-practical transactions with what we call reality. We and nature are both emergent realities which primarily and immediately felt through our embodied experiences. 


\section{TEMPORALITY OF AESTHETIC EXPERIENCE}

Dewey's thick exposition in Art as Experience chiefly focuses on how art relates to the 'temporality' of experience. However, to make sense of this notion of 'temporality' that belongs to experience, we better make a comparison with the one which is mostly 'spatial.' As we have discussed above, experience for Dewey is allencompassing. It envelopes both the experiencer (the human) and the experienced (other humans or things) with an immediately felt pervasive quality. For example, we immediately feel a 'formal' pervasive quality of our office when we attend a meeting, a 'cheerful' quality when we have lunch in the cantina, et cetera. So it can be said that we dwell in multifarious 'spaces' of qualitative meaning. Still, such spaces are banal or mundane because they give us only a fleeting experience, i.e. leaves no strong impression as soon as we no longer dwell in it. However, there is another kind of experience which does not only envelope us in some qualitative spaces but gradually unfolds over time, connecting past, present, and future events then culminate as a whole in a very singular yet deeply meaningful way (Jackson, 1998: 44-45). For this kind of unitary and consummatory experience, Dewey adds an article 'an' in front of the word experience, so it becomes 'an experience.' An experience is precisely Dewey's term for aesthetic experience par excellence.

Some simple examples of 'an experience' is perhaps a graduation day, a successful first concert, the birth of a child, a funeral of the beloved one, et cetera. In attending the funeral of our beloved friend, for example, we are not merely dwelling in a qualitative space called cemetery in a temporally fleeting way. Within some moments of the funeral, our past moment with our friend begin to unfold and flash before our eyes. It does not stop in connecting our present to our past, but it also opens up the future possibilities. Perhaps there are some feeling of guilt of letting our friend down in the past, followed by the feeling of gratitude of enduringly maintaining good friendship until the last moment of her/his life, and this particular yet temporally unfolding experience invites us to become a more caring person in the future. This present experience with connections its to past may still echo for some times ahead, receiving our imaginative selection and refinements, and finally in a consummatory moment (perhaps when we discover that we have become a more caring person), the whole chain of events resolute into its most meaningful whole, giving us 'an experience' of friendship, a special and life changing one.

"We have an experience when the material experienced runs its course to fulfillment. Then and then only is it integrated within and demarcated in the general stream of experience from other experiences. A piece of work is finished in a way that is satisfactory; a problem receives its solution; a game is played through; a situation, whether that of eating a meal, playing a game of chess, carrying on a conversation, writing a book, or taking part in a political campaign, is 
so rounded out that its close is a consummation and not a cessation. Such an experience is a whole and carries with it its own individualizing quality and self-sufficiency. It is an experience." (Dewey, 1988: 42)

The question is then, what is the relationship of an experience with art? To attend to Dewey's answer, we should pay attention not to the 'content' or the story of one's experience, but to its wholistic temporal (i.e., rhythmic) character, structure, or 'form,' which integrates all of its parts in a very engaging and meaningful way (Jackson, 1998: 44-54, Cochran, 2010: 246), a structure which is also akin to work of art in general. An experience of a common person might not be reaching its consummation in the same structural quality as narrative design created by a very good team of movie writer, director and editor. However, that is precisely Dewey's point. Art originates in spatially and temporally structured experiences of common women and men. But its finest example is epitomized, precisely in artworks.

"In short, art, in its form, unites the very same relation of doing and undergoing, outgoing and incoming energy, that makes an experience to be an experience. Because of elimination of all that does not contribute to mutual organization of the factors of both action and reception into one another, and because of selection of just the aspects and traits that contribute to their interpenetration of each other, the product is a work of esthetic art... The doing or making is artistic when the perceived result is of such a nature that its qualities as perceived have controlled the question of production." (Dewey, 1988: 48)

Art as Experience is indeed filled with thick analysis of artwork's structure and process. But Dewey did not apply his analysis exclusively to art objects as in formalism. If we remember his philosophical starting point, Dewey is against dualism which gave birth to formalism, i.e., aesthetic objectivism in art. Since human beings and their environment are interpenetrated to each other spatially and temporally through human experiences, form in Dewey's terminology should be understood as a form of experiences, i.e., signifying the human-environment Spatio-temporal (or stretched and developing) experiential relationships, rather than static or Platonic form of art objects (Alexander, 2016: p. 66).

Another possible objection that can be addressed to Dewey's aesthetics is his rendition of temporality of experience is akin to psychological analysis of mental activities, which at first glance seems to assumes mind-body and inner-outer dualism. But if we read Dewey's notion of experience more carefully, we can also read that his analysis of the temporality of experience is still an extension of his concepts of organism-environment transactions. In Dewey's own words: 
Experience in the degree in which it is experience is heightened vitality. Instead of signifying being shut up within one's own private feelings and sensations, it signifies active and alert commerce with the world; at its height it signifies complete interpenetration of self and the world of objects and events. Instead of signifying surrender to caprice and disorder, it affords our sole demonstration of a stability that is not stagnation but is rhythmic and developing. Because experience is the fulfillment of an organism in its struggles and achievements in a world of things, it is art in germ. (Dewey, 1988: 19)

\section{CONCLUDING REMARKS: THE SIGNIFICANCE OF ART}

As we have discussed, Dewey does not understand art as merely a class of 'object' that covers fiction, entertainment or museum display. He too does not understand aesthetic experience as a merely 'subjectivistic' happening that occurs 'inside' each of our isolated minds. These two inter-related ways of conceiving art, ourselves and aesthetic experience is shown by Dewey as a consequence of an old yet prevailing dualistic metaphysical bifurcation, which compartmentalizes many aspects of life, not to mention inherited us with unsolvable philosophical pseudoproblems, such as: how can we relate our thought inside with reality outside (the problem of scepticism, relativism), and also nihilism (devaluation of the meaning of reality since qualitative meaning is deemed to be a subjective phenomenon, which is also closely tied to modern day's marginalization of art and aesthetic experience). Dewey's notion of experience, as we have seen, is a radical critique and a strong remedy to such fallacy of hypostatization. Experience for Dewey is a relational and temporal term. It refers to life as lived, a directly sensed and everdeveloping context of interactions or transactions between human beings and their world. Within life understood as experience, art for Dewey stands still as a paradigmatic example for consummatory or culminating experience, that is, a series of life experiences in which their driving energies do not dissipate, but form some configurations and each reaches its meaningful closure. To quote Thomas Alexander, 'art' arises in the way human beings express what gives meaning and value to their lives, even where the culture does not have either the idea or a word for 'art' (Alexander, 2016: 64)

Art-related aesthetic experiences integrate the future and the past within the present moments of the artwork's presences or performances. In this case, the creators and the appreciators might both be captivated in the art making/performing/appreciating experiences. However, as one of the leading Dewey scholar Scott Stroud reminds us, "we must never forget that life and the struggles of the living creature - including the living symbol-using creature that is the human - extends beyond the realm of art objects as defined by specific cultural traditions of production and reception. Our activities can hold the same level of 
integration as an art object; the difference is simply in the details" (Stroud, 2014: 44). Instead of immersing in meaningful story line of our favorite film, it might be our current engagement with our work that brings forth the feeling of fulfilment. Nevertheless, it is the 'form of experience' which is present in both instances, i.e., "an attentively engaged present funded by the past and anticipating the future. We can engage this present skillfully" as we were performing artists, or merely doing our work mechanically or randomly (ibid., 2014: 44). The two latter qualities are of course the antinomy of the aesthetic: blindly following procedural mechanism or executing things randomly which hardly ever pave our way to consummatory or culminating experience. In this way, Dewes understanding of art-related aesthetic experience has successfully demonstrated to us what art can do for us in the age of knowledge economy with its overt cyberbureaucratic tendency. Art can teach us about how to live our life in an artful way.

\section{REFERENCES}

Alexander, Thomas M. 2016. "Dewey's Philosophy of Art and Aesthetic Experience." In Artizein: Arts and Teaching Journal, Vol. II, Issue I. Pp. 5967.

Cazeaux, Clive. 2017. Art, Research, Philosophy. Routledge, London.

Cochran, Molly (ed.). 2010. The Cambridge Companion to Dewey. Cambridge University Press, Cambridge.

Dewey, John. 1981. "Experience and Nature." In The Later Works of John Dewey, Vol. 1. Jo Ann Boydston (ed.). Southern Illinois University Press, Carbondale.

. 1988. “Art as Experience." In The Later Works of John Dewey, Vol. 10. Jo Ann Boydston (ed.). Southern Illinois University Press, Carbondale.

Duby, Marc and Barker, Paul A. 2017. "Deterritorialising the Research Space: Artistic Research, Embodied Knowledge, and the Academy." In Sage Open Journal, October-December. Retrieved on September 2019 from https://journals.sagepub.com/doi/10.1177/2158244017737130

Fesmire, Steven. 2015. Dewey. Routledge, London.

Gamo, Marta V. 2011. "John Dewey on the Continuity of Art and Morals within the Consummated Experience." In Art, Emotion and Value. 5th Mediterranean Congress of Aesthetics (conference proceedings). Retrieved on Sept. 2019 from https://www.um.es/vmca/proceedings/docs/8.MartaVaamonde-Gamo.pdf

Jackson, Philip W. 1998. John Dewey and the Lessons of Art. Yale University Press, New Haven. 
Johnson, Mark. 2018. The Aesthetics of Meaning and Thought: The Bodily Roots of Philosophy, Science, Morality, and Art. The University of Chicago Press, Chicago.

Johnson, Mark. 2011. "Embodied Knowing Through Art" in The Routledge Companion to Research in the Arts. Biggs \& Karlsson (eds.). Routledge, London. Pp. 141-151.

Macey, Samuel (ed.). 1994. Encyclopedia of Time. Routledge, New York.

Malachowski, Allan (ed.). 2013. The Cambridge Companion to Pragmatism. Cambridge University Press, Cambridge.

McClelland, Kenneth A. 2005. "John Dewey: Aesthetic Experience and Artful Conduct." In Education and Culture, Vol. 21, No. 2. Pp. 44-62.

Muhit, Md. Abdul. 2013. "Notion of 'Experience' in John Dewey's Philosophy." In Philosophy and Progress, Vols. LIII-LIV, January-June, July-December. Pp. 10-24. ISSN 1607-2278.

Pakes, A. 2004. "Art as Action or Art as Object? The Embodiment of Knowledge in Practice as Research.” In Working Papers in Art and Design, Vol. 3. ISSN 1466-4917.

Ruoppa, Raine. 2019. “John Dewey's Theory of Aesthetic Experience: Bridging the Gap Between Arts and Sciences." In Open Philosophy, Vol. 2, Issue 1. Pp. 59-74. Retrieved on September 2019 from https://www.degruyter.com/view/j/opphil.2019.2.issue-1/opphil-20190007/opphil-2019-0007.xml

Shusterman, Richard. 1997. "The End of Aesthetic Experience." In The Journal of Aesthetics and Art Criticism, Vol. 55, No. 1. Pp. 29-41.

Shusterman, Richard. 2012. "Back to the Future: Aesthetics Today." In The Nordic Journal of Aesthetics, No. 43. Pp. 104-124.

Stroud, Scott R. 2014. "The Art of Experience: Dewey on the Aesthetic." In Practicing Pragmatist Aesthetics: Critical Perspectives on the Arts. Wojciech Malecki (ed.). Rodopi, Amsterdam. Pp. 33-46. 